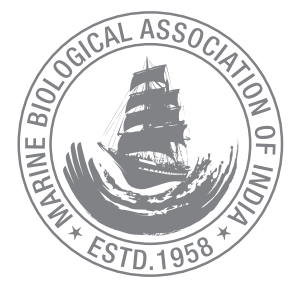

\title{
First record of long-tailed pelagic sea slug Stylocheilus longicauda (Gastropoda: Opisthobranchia) from southwest coast of India
}

\author{
S. Chinnadurai ${ }^{*}$, Vishal Bhave', Deepak Apte1 and K. S. Mohamed \\ Central Marine Fisheries Research Institute, Kochi- 682 018, Kerala, India \\ 1 Bombay Natural History Society, S.B. Singh Road, Mumbai, Maharashtra, India- 400001. \\ *Correspondence e-mail: chinnaduraitvl@gmail.com
}

Received: 23 May 2014, Accepted: 30 Jul 2014, Published: 15 Nov 2014

Original Article

\begin{abstract}
The long-tailed sea slug Stylocheilus longicauda was recorded for the first time from southwest coast of India. A single specimen measuring a total length of $70.51 \mathrm{~mm}$ was collected from a floating bottle, along with bunch of goose-neck barnacles from Arabian sea off Narakkal, Vypeen Island, Kochi. Earlier identifications were made based on the morphology of the animal without resorting to description of radula. This makes it difficult to differentiate the species from Stylocheilus striatus which has similar characters. The present description details the external and radular morphology of Stylocheilus longicauda.
\end{abstract}

Keywords: Mollusca, Opisthobranch, Aplysia, long-tailed sea slug.

\section{Introduction}

Opisthobranchs are the third largest group of snails, apart from prosobranchs and pulmonate snails. Opisthobranch [Mollusca: Gastropoda] are currently divided into nine main clades: Cephalaspidea, Thecosomata, Gymnosomata,
Aplysiomorpha, Acochlidiacea, Sacoglossa, Cylindrobullida, Umbraculida and Nudipleura (Bouchet and Rocroi, 2005). In clade Aplysiomorpha, (clade to which sea slugs belongs) shell is small (in some it is lost) and covered by mantle and it is absent in nudibranchs. Sea hares or sea slugs belong to the family Aplysiidae. These gastropods breathe either through gills, which are located behind the heart, or through the body surface. The sea hares are characterized by a shell reduced to a flat plate, prominent tentacles (resembling rabbit ears), and a smooth or warty body. Sea hares eat large seaweeds, and all are simultaneous hermaphrodites. Their common name derives from their resemblance of rabbit when they are seen grazing on a strand of seaweed.

The long-tail pelagic sea slug Stylocheilus longicauda has many synonyms. They are Aplysia longicauda (Quoyand Gaimard, 1825); Aplysia (Notarchus) citrina (Rang, 1828); Aplysia nudata (Rang, 1828); Aplysia ocellata (Rang, 1828); Aplysia striata (Quoy and Gaimard 1832); Stylocheilus striatus (Quoy and Gaimard, 1832) and Stylocheilus citrina (Marcus 1962; 1972). The Stylocheilus longicauda has been recorded in Kenya, Indonesia, Philipines, Thailand, Iran, Venezeula, Tanzania, Malaysia, Australia, Solomon Islands, French Polynesia, Maldives, South Africa, Mexico and Andaman and Nicobar Island in India. 


\section{Material and methods}

A floating glass bottle (made in India) was found near the shore of Narakkal, Vypeen Island, Kochi (Fig.1, Lat. $10^{\circ} 02^{\prime} 31.60^{\prime \prime} \mathrm{N}$ and Long. $\left.76^{\circ} 12^{\prime} 22.29^{\prime \prime} \mathrm{E}\right)$, west coast of India at $09.45 \mathrm{a} . \mathrm{m}$ on 8 May, 2013. A single specimen of bright yellow colored sea slug was found attached to the bottle together with gooseneck barnacle, Lepas spp (Fig. 2 A\&B). For identification and studying the behaviour of the animal, it was transferred along with the bottle to CMFRI-NAIP oyster hatchery at Narakkal. The collected animal was kept alive in 50 litre fiberglass tank for further studies. The well aerated tank was, filled with UV treated seawater and fed with Isochrysis galbana. A purple color mucus-like secretion was observed from the ink gland beneath parapodial opening, when the animal was disturbed. This may be due to irritation or as a defense mechanism (Wagele et al., 2006). After a week, the whole animal was preserved in $4 \%$ formalin and sent to Bombay Natural History Society Museum for depositing the animal (Accession No:BNHS-OPISTHO-965) and for further study of the radular morphology of the animal. Identification made was based on the morphology and radula using key provided by Bebbington (1974).

\section{Results}

\section{Systematics}

Sub class: Opisthobranchia

Order : Anaspidea Fisher, 1883

Family : Aplysiidae Lamarck, 1809

Genus : Stylocheilus Gould,1852

Species: Stylocheilus longicauda (Quoy \& Gaimard, 1825).

\section{Description}

\section{External morphology}

The body of the animal (Fig. 2C) was elongate with maximum crawling length about $70.51 \mathrm{~mm}$. The dorsal colour of the animal was bright yellowish-green with blue spots circled with orange-red. The ventral side of the animal was paleyellow in colour. Several small papillae were scattered on the dorsal surface and few larger branched papillae were present around the genital opening. The tail of the animal was long, slender (nearly half of total length), and almost ribbon-like structure. A pair of tubular, elongated, oral tentacles and rhinophores were present above the head. Clearly visible penis (white half-moon structure) was observed on the right side of the head. Based on the key given by Bebbington (1974), following characters identified the species as $S$. longicauda. Parapodia equal, small in size, shape and lightly fastened. Skin with simple and compound villi. Shell absent,

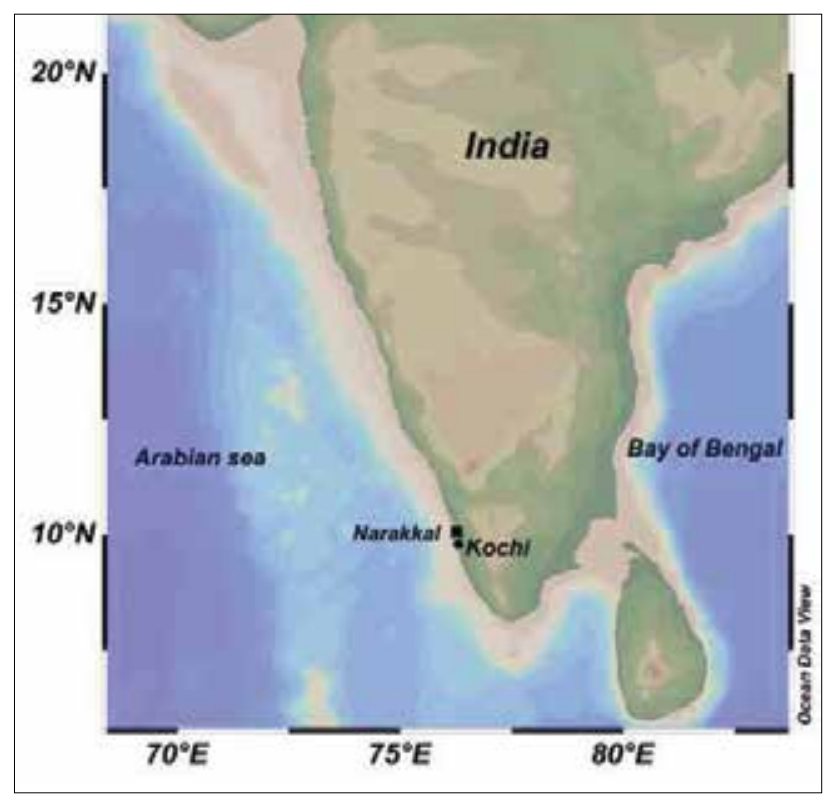

Fig.1. Map showing the collection sites of Stylocheilus longicauda in west coast of India.

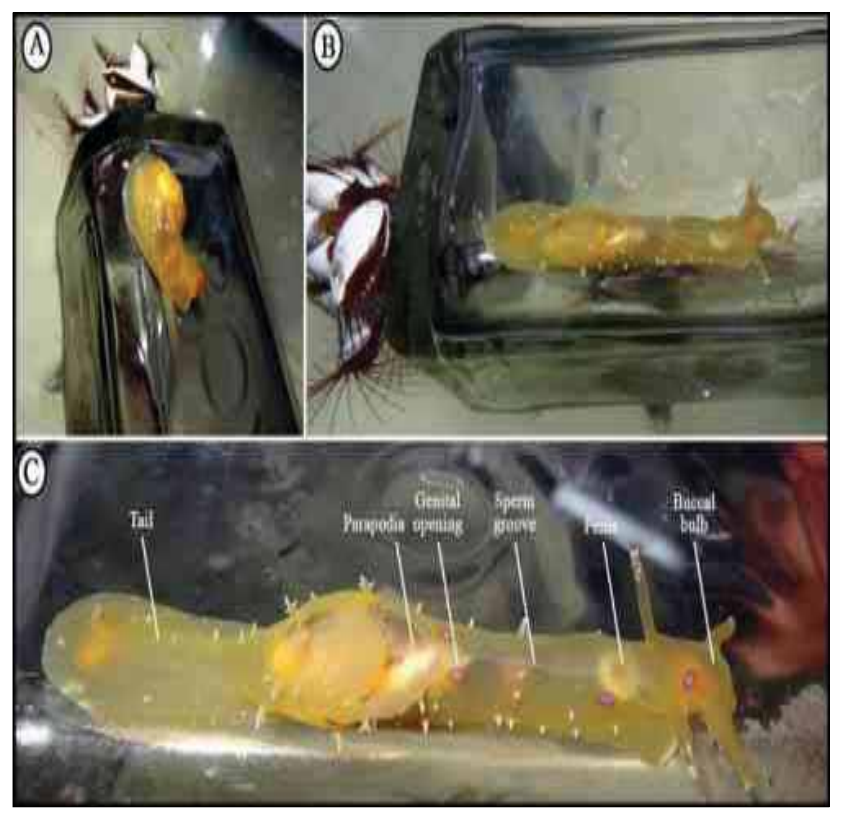

Fig.2.A \& B Stylocheilus longicauda with gooseneck barnacle; C External morphology of the specimen (BHNS-OPISTHO-965) of Stylocheilus longicauda from Kochi, west coast of India.

foot moderately broad, prolonged posteriorly as a slender tail. Hermaphrodite opening outside dorsal slit.

\section{Radular morphology}

Jaws and radular teeth structure matched with those given by Bebbington (1974). Jaws were made up of rods densely packed (Fig. 3A \& B) to form two plates on either sides of 

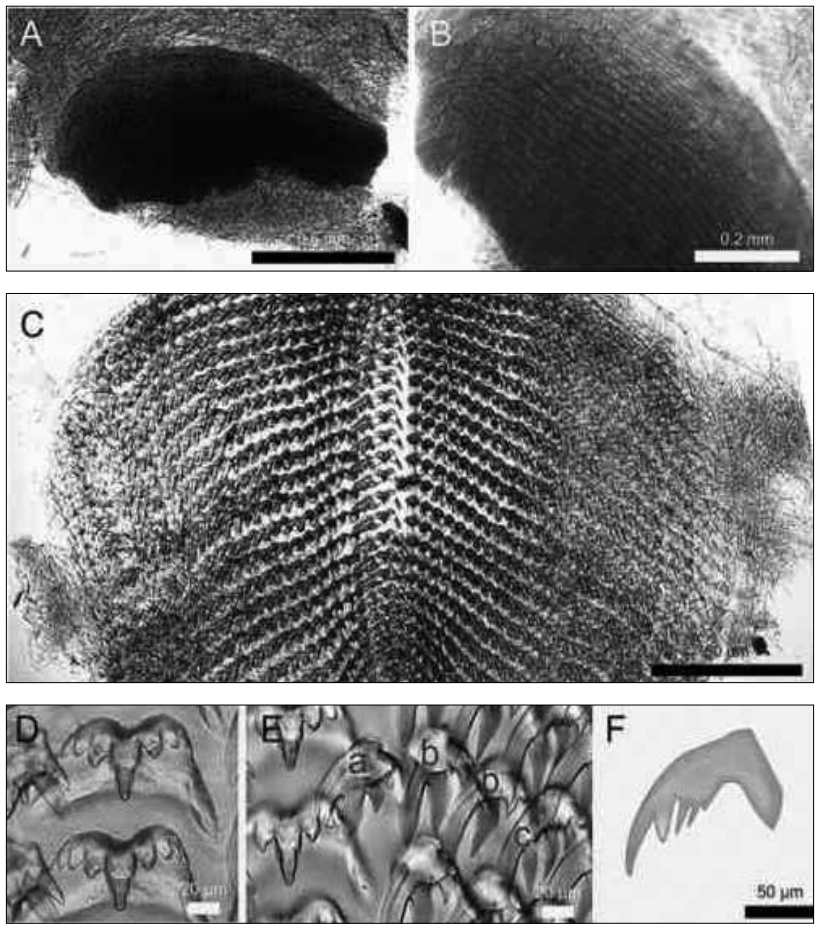

Fig.3 Stylocheilus longicauda (BHNS-OPISTHO-965) A Jaw plate; B Jaw close up; C Radula; D Rachidean teeth; E Laterals a- 1st inner lateral; b- 2nd inner lateral (2); c- 4th inner lateral ( $~ 8-12$ nos); F Outer lateral.

the mouth, thicker than the radular ribbon (Fig. 3C). Radular formula was $27 \times 34.1 .34$, with rachidean teeth having broad base, tip little narrow and a single large cusp flanked by the 3 smaller cusps, posteriorly curved (Fig. 3D). Median cups of rachidean teeth have three lateral denticles. Four variations/ types of lateral teeth were observed. Innermost lateral teeth were with broad head with five dagger shaped cusp posteriolaterally (Fig. 3E: a). The number of denticles/cusps reduced from inner lateral to outer laterals (Bebbington, 1974) (Fig. $3 \mathrm{E}: \mathrm{a}-\mathrm{c})$.However, in the outer laterals, the current specimen had more number of denticles along the inner margin anteriorly on the outer lateral (Fig. 3F).

\section{Discussion}

Opisthobranchs are marine gastropods which are found throughout the world. Most of them are marine and very few are found in freshwater ecosystems. Approximately 6,000 species of opisthobranch were reported globally (Wagele et al., 2008). Under family Aplysiidae, 80 species were recorded worldwide, and 19 species of Aplysiomorpha has been recorded from the Indian Ocean (Bebbington, 1974). In India, the species Stylocheilus longicauda was first reported from Pondicherry coast, Bay of Bengal by Gibson (2002) and subsequently by Ramakrishna et al (2010) from Andaman Islands.
For a long time, the name Stylocheilus longicauda was used for the more common species Stylocheilus striatus. According to Rudman (1999) nomenclatural discussion, there was a huge confusion between the identification of $S$. longicauda and S. striatus described by Quoy and Gaimard (1832). Based on the external body shape and background colour, Rudman (1999) reproduced the original figures of the early Stylocheilus names. Stylocheilus striatus has a much shorter 'tail', usually less than one third of the total body length while in Stylocheilus longicauda, as its name implies, the 'tail' is up to half the total body length. Stylocheilus striatus has a translucent body with patches of greens, browns and white, and often with many branched papillae. The background colour of Stylocheilus longicauda, on the other hand, is a uniform yellow or green, and papillae are sparse and seldom branched. Ecologically they are quite different, Stylocheilus longicauda having a circum tropical distribution as a pelagic animal drifting on floating algae and other floating objects, while Stylocheilus striatus is a circum-tropical shallow water bottom-dweller. The history of Stylocheilus is also complicated, with two very different forms inhabiting very different environments. Clearly the aplysiids are in need of revision, entailing comparison of specimens from different regions and habitats as well as a very thorough review of the literature; it is probable that the numerous species names currently listed will dissolve into fewer, variable species (Yonow, 2012).

The main evolutionary trend in Opisthobranchia is reduction or even loss of the shell (Grande et al., 2004) accompanied by development of diverse defensive strategies (Wagele and Klussmann-Kolb, 2005). According to Cimino and Ghiselin (1999), the chemical defence is the driving force of opisthobranch evolution. The chemical ecology of this group is particularly appealing since most species have a reduced or lack of shell and have developed chemical defence to avoid predation (Wagele et al., 2006). Thompson and Slinn (1959) dealt with single species of opisthobranch, Pleurobranchus membranaceus, which proved to be able to secrete a strong acid if disturbed and recorded further instances of acid secretion (Thompson, 1960). We also observed a purple colour mucus-like secretion from the parapodial opening, when the animal was touched or disturbed and further it shrank into small round shape without any active movement.

Jenson (2006), found that many floating pumice rubble in South Pacific Coral Sea, were covered with gooseneck barnacles along with little yellow sea hares (Stylocheilus longicauda). Rick (2009) also reported two specimens of Stylocheilus longicauda found along with goose-neck barnacle in northern New South Wales. Similarly, we observed the same sea slug, on a bottle along with a bunch of goose-neck barnacles. The 
ecological relationship between these two animals is not known. Although, this sea slug is normally found along with seaweeds, the present specimen was not having any seaweed flora attached. It is quite likely that the origins of these two species are the Lakshadweep Islands, from where the bottle has drifted to the southwest coast of India due to prevailing wind and current patterns.

Recent studies on opisthobranch in India have resulted in many new records (Apte, 2009; Apte and Salahuddin, 2010; Apte et al., 2010; Bhave and Apte, 2011; Sankar et al., 2011; Dhivya et al., 2012), however most of the studies were confined to the intertidal reef habitats of the east coast (Alder and Hancock, 1864; Satyamurthi, 1952; Rao, 1962, Ramakrishna et al., 2010; Sreeraj et al., 2012) and on the northwest coast (Narayanan, 1968, 1971; Rao et al., 1974; Apte, 2009; Apte et al., 2010; Bhave and Apte, 2011), which suggests that a systematic study of the opisthobranch fauna in Indian waters would likely identify a greater diversity.

\section{Acknowledgements}

The authors are grateful to the Director, Central Marine Fisheries Research Institute (CMFRI), Kochi for facilities and encouragements. Authors are also thankful to $S$. Dinesh Kumar for photography.

\section{References}

Alder, J., and A. Hancock. 1864. Notice of the collection of nudibranchiate Mollusca made in India by Walter Elliot Esq., with descriptions of several new genera and species. Trans. Zoo. Soc. London, 5: 113-147.

Apte, D. 2009. Ophisthobranch fauna of Lakshadweep Islands, India with 52 new records to Lakshadweep and 40 new records to India. J. Bombay Nat. Hist. Soc., 106 (2): 162-175.

Apte, D. and V. K. Salahuddin. 2010. Record of Hexabranchus sanguineus (Ruppell and Leuckart 1828) from Lakshadweep Archipelago, India. J. Bombay Nat. Hist. Soc,, 107(3): 261-262.

Apte, D., V. Bhave. and D. Parasharya. 2010. An annotated and illustrated checklist of the opisthobranch fauna of Gulf of Kutch, Gujarat, India with 21 new records for Gujarat and 13 new records for India: part 1. J. Bombay Nat. Hist. Soc., 107(1): 14-23.

Bebbington, A. 1974. Aplysiid species from East Africa with notes on the Indian Ocean Aplysiomorpha (Gastropoda:Opisthobranchia). Zoo. J. Linn. Society, 54: 63-99.

Bhave, V. and D. Apte. 2011. Opisthobranch fauna of Ratnagiri, Maharashtra, India with 8 new records to India. J. Bombay Nat. Hist. Soc., 108(3): 172-182.

Bouchet, P. and J. P. Rocroi. 2005. Classification and Nomenclature of Gastropod families. Malacologia, 47 (1-2): 397 pp.
Cimino, G. and M. T. Ghiselin. 1999. Chemical defence and evolutionary trends in biosynthetic capacity among dorid nudibranchs (Mollusca: Gastropoda: Opisthobranchia). Chemoecology, 9: 187-207.

Dhivya, P., V. Sachithanandam. and P. M. Mohan. 2012. New records on the opisthobranch fauna of the Andaman Islands, India. Indian J. Geo Mar. Sciences, 41(3): 215-217.

Grande, C., J. Templado., J. L. Cervera. and R. Zardoya. 2004. Phylogenetic relationships among Opisthobranchia (Mollusca: Gastropoda) based on mitochondrial cox1, trnV and rrL genes. Mol. Phyl. and Evolution, 33: 378-388.

Gibson, B. 2002. Stylocheilus longicauda from India. [Message in] Sea Slug Forum. Australian Museum, Sydney. Available from http://www.seaslugforum.net/ find $/ 8106$

Jensen, K. R. 2006. Sea hares on floating pumice. [Message in] Sea Slug Forum. Australian Museum, Sydney. Available from http://www.seaslugforum.net/ find/19091

Narayanan, K. R. 1968. On three opisthobranchs from the south-west coast of India. J. Mar. Biol. Ass. India, 10(2): 377-380.

Narayanan, K. R. 1971. On two doridacean nudibranchs (Mollusca:Gastropoda) from the Gulf of Kutch, new to Indian coast. Advance Abstracts of Contributions on Fisheries and Aquatic Sciences in India, 4(4): 313-314.

Ramakrishna, C. R., C. Sreeraj., C. Raghunathan., J. S. Sivaperuman., R. Yogesh Kumar., R. Raghuraman., T. Immanuel. and P. T. Rajan. 2010. Guide to Opisthobranchs of Andaman and Nicobar Islands. Zoological Survey of India, Kolkata, 187 pp.

Rao, K. V. 1962. On two opisthobranchiate molluscs, Placobranchus ocellatus Hasselt and Discodoris boholiensis Bergh, from Indian waters not hitherto been recorded. J. Mar. Biol. Ass. India, 3(1-2): 253-256.

Rao, K. V., P. Sivadas. and L. K. Kumari. 1974. On three rare doridiform nudibranch molluscs from Kavaratti Lagoon, Laccadive Islands. J. Mar. Biol. Ass. India, 16(1): 113-125.

Rick D. 2009. http://www.seaslugforum.net/showall/stylcaud

Rudman, W. B. 1999. Stylocheilus longicauda \& Stylocheilus citrina Nomenclatural discussion. [In] Sea Slug Forum. Australian Museum, Sydney. Available from http://www.seaslugforum.net/factsheet/stylnome

Sankar, R., P. Raja. and A. Murugan. 2011. Occurrence of ophisthobranch mollusk Umbraculum umbraculum in Tuticotin coast, South east coast of India. Indian $J$. Geo Mar. Sciences, 40(4): 487-490.

Satyamurti, S. T. 1952. The Mollusca of Krusadai Island (in the Gulf of Mannar). Bulletin of Madras Government Museum, New series, Natural history section 1, 1-258, pls. 1-34.

Sreeraj, C. R., C. Sivaperuman. and C. Raghunathan. 2012. Report on ten newly recorded Opisthobranchs (Opisthobranchia, Gastropoda) from Andaman and Nicobar Islands, India. Int. J. Oceano. Mar. Eco. System, 1(2): 50-59; http://dx.doi. org/10.3923/ijomes.2012.50.59

Thompson, T. E. 1960. Defensive adaptations in opisthobranchs. J. Mar. Biol. Ass. UK, 39: 123-134. doi:10.1017/50025315400013163.

Thompson, T. E. and D. J. Slinn. 1959. On the biology of the opisthobranch Pleurobranchus membranaceus. J. Mar. Biol. Ass. UK, 38: 507-524.

Wagele, H. and A. Klussmann-Kolb. 2005. Opisthobranchia (Mollusca, Gastropoda) more than just slimy slugs. Shell reduction and its implications on defence and foraging. Frontiers in Zoology 2, 3.

Wagele, H., M. Ballesteros. and C. Avila. 2006. Defensive glandular structures in opisthobranch molluscs - From histology to ecology. Oceano. and Mar. Bio. Annual Review, 44: 197-276.

Wagele, H., A. Klussmann-Kolb., V. Vonnemann. and M. Medina. 2008. Heterobranchia I. The Opisthobranchia. In: WF Ponder, DR Lindberg, Eds, Phylogeny and evolution of the Mollusca, University of California Press, Berkeley, 385-408 pp.

Yonow, N. 2012. Ophisthobranchs from the western Indian Ocean, with descriptions of two new species and eleven new records (Mollusca: Gastropoda). Zookeys, 197: 1-130. 